\title{
Prioritizing Infection Prevention and Control Activities for SARS-CoV-2 (COVID-I9): A Multi-Criteria Decision-Analysis Method
}

This article was published in the following Dove Press journal: Journal of Healthcare Leadership

\section{Adnan Sarwar \\ Muhammad Imran}

Department of Economics and Business Management, University of Veterinary and Animal Sciences, Lahore, Pakistan
Correspondence: Adnan Sarwar Department of Economics and Business Management, University of Veterinary and Animal Sciences, Lahore, Pakistan Tel +923007699710

Email adnansarwar@live.com
Purpose: The outbreak of COVID-19 in China has spread to the whole world within a short period. The spread of COVID-19 has caused innumerable economic and social losses. The coronavirus spread directly from individual to individual. WHO and other governing bodies made guidelines and remedial activities to minimize the spread of COVID-19. This study aims to analyze and prioritize infection prevention and control activities for SARS-CoV-2.

Methods: An analytical study was conducted between medical representatives and scientists to check the impact of these precautionary measures (social distancing, shaking hands and hugging peoples, unnecessary touching things, hygiene, and sharing personal items) on COVID-19. The Analytical Hierarchical Process (AHP) method has been utilized to evaluate and prioritize the preventive measures of COVID-19.

Results: The results of this investigation shows, unnecessary travel, 3Cs, and touching own body parts should be avoided. Wearing a mask and proper hand washing are important to reduce the spread of coronavirus.

Conclusion: The SARS-CoV-2 has affected more than 11 million people around the world. The second spike of COVID-19 is also alarming for people. It is important to follow the instruction provided by the $\mathrm{WHO}, \mathrm{CDC}$, and other national and international governing bodies. The AHP method was used to check various measures that are spreading the coronavirus disease. It demonstrated that $3 \mathrm{Cs}$ (spaces that are closed, crowded, and involve close contacts) and travel, shaking hand, unnecessary touching own body parts should be avoided.

Keywords: pandemic COVID-19, preventive measure, decision making, AHP, SARS-CoV-2

\section{Introduction}

COVID-19 which was first found in Wuhan city of China was soon listed as a public health emergency of international concern by the Emergency Committee of the World Health Organization (WHO). The virus is transmitted directly from infected people (saliva and discharge of nose). Individual may also be infected by touching their own body parts (eyes, nose, and mouth) and touching the surfaces of contaminated. ${ }^{1}$ COVID-19 is also spread through liquid particles such as coughing, speaking, shouting, and breathing. ${ }^{2,3}$ It did not take a long time to spread to other parts of the world. According to John Hopkins University, to date, it has affected 37 million people globally and caused 1 million deaths. The swift spread of COVID has not only affected the lives of millions of people, but it has also resulted in countless economic and social losses. So far, the United States, India, and Brazil are 
badly affected by its spread. While in some countries, cases are declining, and some other countries are seeing spikes. The countries like Austria, China, and Singapore which have uplifted lockdowns and eased the rule of social distancing are placing to prevent coronavirus. Some countries are under lockdown again, faced with the threat of a second wave of COVID., ${ }^{4,5}$ Experts are warning about the possibilities of the second wave attributed mainly to human behavior. People were frustrated after being at home for a long time and now breaking all the social rules. Analysis of cellphone data shows a declined social distancing. As a result, some experts have warned that the second wave could be more severe. Most of the predictions about COVID-19 by experts are based on studying the behavior of other viruses such as the $1918 \mathrm{flu}$ pandemic and the 2009 H1N1 flu epidemic. ${ }^{6}$

In earlier days, many countries in the world announced lockdowns to curb the spread of virus. However, from an economic standpoint, there's a greater trade-off between saving lives and saving livelihood. Shutting the economy threatens the livelihood of the hundreds of millions of poor, especially in developing countries where government support has been minimal. Policy decisions made during the first wave of COVID-19, have varying impacts in different countries. Due to differences in actions the magnitude of impacts has also varied a lot between countries. Some of the countries have been successful in controlling the spread of disease and some have been worst hit by the virus. A Pew Research Center survey of more than 14,000 adults across 14 advanced economies in Europe, Asia, North America, and Australia, found 73\% thought their own country had done a good job of tackling the coronavirus outbreak. Countries like Australia and Denmark got the highest response approval rating from the citizens. Due to delayed action in combating COVID-19 countries like the UK and the US received less emphatic support from their citizens (WEF, 2020).

A renaissance of COVID-19 is a threat to the world according to the World Health Organization. With the country's uplifting lockdown, educational institutes being opened, international travel being resumed, there's a greater threat of a resurgence of COVID-19 due to many unwitting coronavirus carriers in different areas. It's a challenge because now it will make it harder to detect and control transmission, unlike the previous, when we had the opportunity to contact, trace, and quarantine (John Hopkins University). While some countries are facing a second wave and some countries are at risk to follow the same pattern, national and global health bodies are constantly updating their guidelines to curb the spread of COVID-19. Researchers around the globe are working day and night to find vaccines for COVID-19. Unprecedented cooperation has been seen between public and private health organizations during the pandemic. Many health organizations are working with biopharmaceutical companies to accelerate the process of finding a drug or vaccine for novel coronavirus. Up to now, different vaccines have been produced and being approved by health bodies of countries across the globe. ${ }^{7}$ However, universal access to the vaccine is a major challenge for many countries especially resource-poor countries. Additionally, a new variant of the virus is posing threat to scientific achievement against COVID-19. Taking into consideration the above situation, following early mentioned precautionary measures is the wise thing to do, until, we reach universal vaccination.

Various health bodies like WHO, CDC, etc. are calling for curbing further spread of coronavirus by adopting different measures. Global and national health bodies have been advising to adopt different strategies to slow down the spread. One earliest and common advice was to avoid unnecessary travel, 3Cs, and contact with people having COVID-19 symptoms. Authorities have been recommending wearing a face mask, frequently wash and sanitize hands, and use hand gloves, etc. ${ }^{8}$ Massive awareness campaigns have been launched by government bodies to educate citizens about safety measures during the pandemic. Information technology companies have also developed applications to provide up-to-date information about coronavirus outbreak. ${ }^{9}$

National Governments have been continuously advised by global (WHO, UNICEF, CDC, etc.) and national health bodies to adopt/enforce different measures to control the spread of COVID-19. These activities include identification, diagnosis, and management of the cases, control and prevention in healthcare settings, implementation of health measures for travelers, and risk communication. ${ }^{10}$ The spread of COVID-19 can also be control by public intelligence and social awareness. Various social and physical measures such as social and physical distancing, outdoor use of face masks, restraining from unnecessary travel, hygiene, proper nutrition, health monitoring, etc. have been recommended by global health bodies. ${ }^{10}$ However, the adoption of all recommendations at an equal level by people is an unrealistic hope. Therefore, there is a need to priorities those measures which are more helpful in 
curtailing the spread as compared to those which have less impact. ${ }^{11}$ In this situation, decision making is influenced by several precautionary measures. Therefore, it is important to consider those decision-making methods that help to analyze and prioritize precautionary measures. This is a complex decision-making process to determine priority order. $^{12}$ The most appropriate way to achieve this is the Multi-Criteria Decision Making Analysis technique such as Analytical Hierarchical Process (AHP). It is one of the most important methods that has been applied in the presence of several criteria. ${ }^{13}$ The AHP method is utilized to construct the hierarchal framework of a decision problem using different preventive measures recommended by global health bodies. The hierarchical structure of preventive measure is presented in Figure 1.

\section{Method}

\section{The Analytical Hierarchal Process}

The Analytical Hierarchal Process method was introduced by Saaty. ${ }^{14}$ It is a powerful method for analyzing complex decision-making problems based on mathematics. It has been extensively studied and refined. It

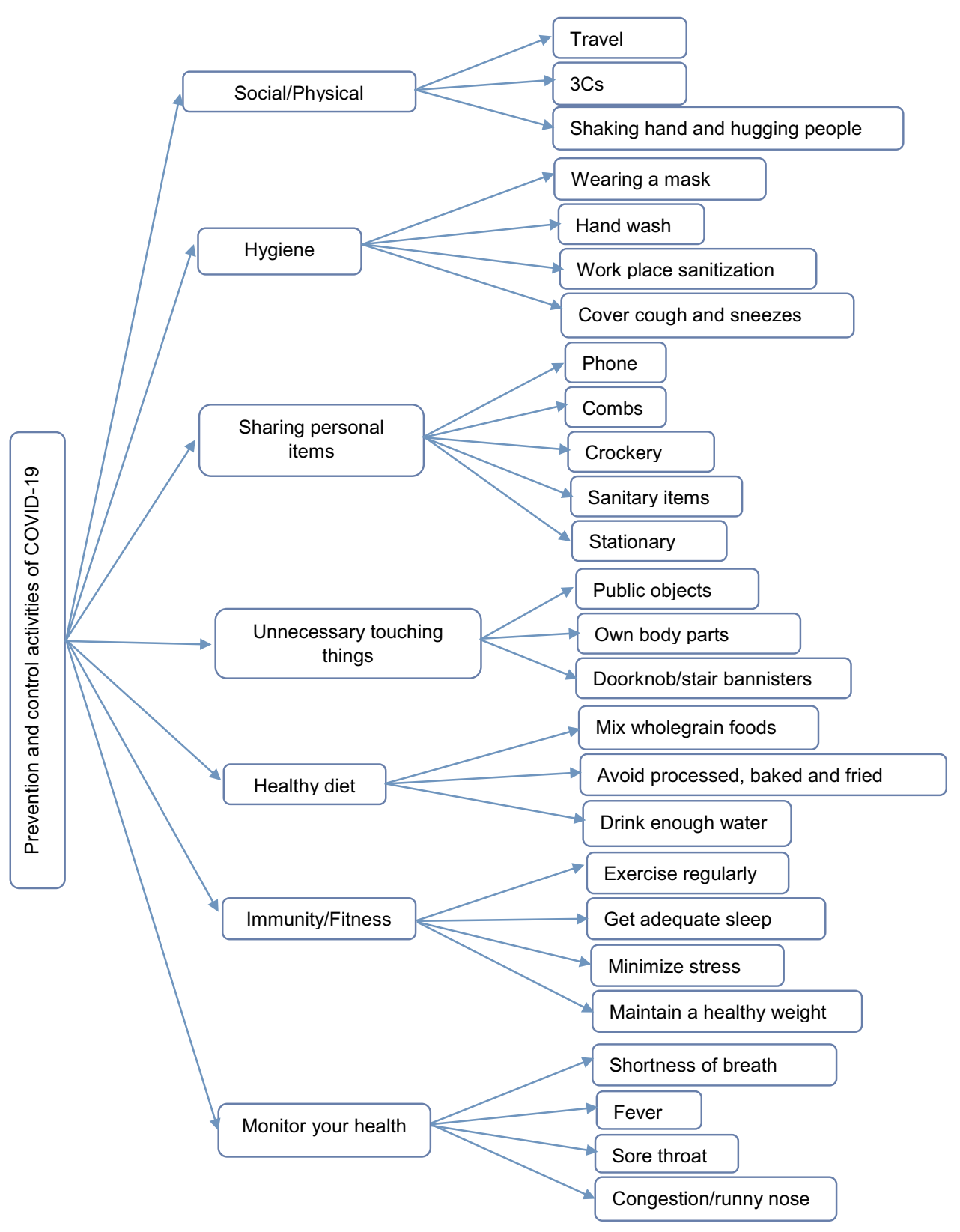

Figure I The hierarchical structure of preventive measures.

Note: Data from Gao and Yu, ${ }^{1}$ US CDC, ${ }^{2}$ and WHO. ${ }^{3}$ 
is an accurate method to develop a rational framework of the problems and quantify its criteria for evaluation. ${ }^{15}$ AHP method consists of two phases: 1) Develop the hierarchal structure of decision-making problems, 2) assign the weights to the decision criteria to determine the priorities of alternatives.

An AHP and F-VIKOR were used to develop an integrated management system while considering the needs and expectations of the stakeholders. ${ }^{16} \mathrm{~A}$ fuzzy AHP-TOPSIS was utilized to conduct a comparison of five hydrometallurgical processes to recover the copper. ${ }^{17}$ The authors proposed five decision-making methods AHP, FAHP, TOPSIS, FTOPSIS, and PROMETHEE evaluate road segments and the safety level of the roads. The AHP, FAHP, and PROMETHEE methods show better performance as compare to others. ${ }^{18}$ This methodology helps the decision-maker to rationalize select and rank complex criteria. The procedure of AHP methodology is as follow:

- Construct the hierarchal framework of a decision problem

- Develop a pairwise comparison matrix of decision problem using Saaty's scale

- Calculate the consistency index (CI)

- To calculate the CI of the pairwise comparison matrix, Lambda max (eigenvalue) is required, and $\mathrm{n}$ represents the number of criteria. The CI formula is presented in Equation 1.

$$
\mathrm{CI}=\frac{\lambda_{\max }-\mathrm{n}}{\mathrm{n}-1}
$$

Compute consistency ratio (CR). The consistency ratio can be computed by Equation 2 .

$$
C R=\frac{C I}{R I}
$$

Table I Main Criteria and Sub-Criteria

\begin{tabular}{|l|l|}
\hline Criteria & Sub-Criteria \\
\hline Social distance (SD) & $\begin{array}{l}\text { Travel SDI, 3Cs SD2, shaking hands and } \\
\text { hugging people SD3 }\end{array}$ \\
\hline Hygiene (H) & $\begin{array}{l}\text { Wearing a mask HI, hand wash H2, } \\
\text { workplace sanitization H3 }\end{array}$ \\
\hline $\begin{array}{l}\text { Sharing personal } \\
\text { items (SPI) }\end{array}$ & $\begin{array}{l}\text { Phone SPII, combs SPI2, crockery SPI3, } \\
\text { sanitary items SPI4, stationery SPI5 }\end{array}$ \\
\hline $\begin{array}{l}\text { Unnecessary touching } \\
\text { things (UTT) }\end{array}$ & $\begin{array}{l}\text { Public objects UTTI, own body parts UTT2, } \\
\text { Doorknob/stair bannisters UTT3 }\end{array}$ \\
\hline Healthy Diet (HD) & $\begin{array}{l}\text { Mix whole grain foods HDI, avoid } \\
\text { processed, baked, and fried foods HD2, } \\
\text { drink enough water HD3 }\end{array}$ \\
\hline Immunity/Fitness (I/F) & $\begin{array}{l}\text { Exercise regularly I/FI, get adequate sleep I/ } \\
\text { F2, minimize stress I/F3, maintain a healthy } \\
\text { weight I/F4 }\end{array}$ \\
\hline $\begin{array}{l}\text { Monitor your health } \\
\text { (MH) }\end{array}$ & $\begin{array}{l}\text { Shortness of breath MHI, fever MH2, sore } \\
\text { throat MH3, congestion/runny nose MH4. }\end{array}$ \\
\hline
\end{tabular}

Note: Data from Gao and Yu,' US CDC, ${ }^{2}$ and WHO. ${ }^{3}$

According to Saaty the value of CR must be within the limit of 0.1 . If it exceeds revision of the pairwise comparison matrix is needed.

\section{Results}

For this research, the pandemic COVID-19 prevention measure has been selected. As we know WHO and other governing bodies of various countries have issued guidelines for precautionary measures of COVID-19. The Pakistani Govt have also provided various guidelines to curb the spread of the virus. The preventive measures (criteria) and sub-criteria are shown in Table 1. The prevention measure consists of seven main criteria along with twenty-six sub-criteria. A multi-criteria decision-making method has been used to construct the pairwise

Table 2 Pairwise Comparison Matrix of Preventive Measure, Ranking, and CR

\begin{tabular}{|l|l|l|l|l|l|l|l|l|l|l|}
\hline Preventive Measures & SD & H & SPI & UTT & HD & I/F & MH & Priority Weights & Rank \\
\hline Social distance (SD) & I & 4 & 3 & 5 & 3 & 5 & 4 & 0.36525 & I & $\mathrm{Cl}=0.062963$ \\
Hygiene (H) & & $\mathrm{I}$ & $\mathrm{I}$ & 0.50 & 3 & 2 & 2 & 0.11736 & 4 & \\
Sharing personal items (SPI) & & & $\mathrm{I}$ & 0.50 & 3 & $\mathrm{I}$ & 3 & 0.12494 & 3 & \\
Unnecessary touching things (UTT) & & & & $\mathrm{I}$ & 3 & 5 & 2 & 0.17976 & 2 & $\mathrm{CR}=0.047699$ \\
Healthy diet (HD) & & & & & $\mathrm{I}$ & 0.50 & 0.33 & 0.05052 & 7 & $\mathrm{RI}=\mathrm{I.32}$ \\
Immunity/fitness (I/F) & & & & & & $\mathrm{I}$ & 0.33 & 0.06663 & 6 & \\
Monitor your health (MH) & & & & & & & $\mathrm{I}$ & 0.09553 & & 5 \\
\hline
\end{tabular}


Table 3 COVID-19 Preventive Measures (PM), Their Ranking/Priorities, and a Brief Description

\begin{tabular}{|c|c|c|c|c|c|c|}
\hline $\begin{array}{l}\text { PM } \\
\text { Codes }\end{array}$ & Criteria & $\begin{array}{l}\text { Weight } \\
\text { of Main } \\
\text { Criteria }\end{array}$ & $\begin{array}{l}\text { Weight } \\
\text { of Sub- } \\
\text { Criteria }\end{array}$ & $\begin{array}{l}\text { Global } \\
\text { Weights }\end{array}$ & Rank & Brief Description \\
\hline SD & Social distance & 0.36525 & & & & $\begin{array}{l}\text { Social distancing also called physical distancing, means keeping } \\
\text { a safe distance between you and yourself. WHO and CDC } \\
\text { strongly recommend a safe distance to minimize the spread of } \\
\text { COVID-19. }\end{array}$ \\
\hline SDI & Travel & & 0.59167 & 0.21611 & $\mathrm{I}$ & $\begin{array}{l}\text { Unnecessary travel of people is a violation of social distance and } \\
\text { may increase the chance of getting and spreading COVID-19. }\end{array}$ \\
\hline SD2 & $3 \mathrm{Cs}$ & & 0.29173 & 0.10655 & 2 & $\begin{array}{l}\text { WHO recommends avoiding } 3 \mathrm{Cs} \text { : spaces that are closed, } \\
\text { crowded, and involve close contacts. }\end{array}$ \\
\hline SD3 & $\begin{array}{l}\text { Shaking hands } \\
\text { and hugging } \\
\text { people }\end{array}$ & & 0.11660 & 0.04259 & 7 & $\begin{array}{l}\text { Shaking hands and hugging people is a way of transferring the virus } \\
\text { from one person to another. People should avoid hugging to } \\
\text { reduce infection. }\end{array}$ \\
\hline $\mathrm{H}$ & Hygiene & 0.11736 & & & & $\begin{array}{l}\text { Hygiene is extremely important in limiting the transmission of the } \\
\text { COVID-19 virus. }\end{array}$ \\
\hline $\mathrm{HI}$ & Wearing a mask & & 0.52233 & 0.06130 & 4 & $\begin{array}{l}\text { Wearing a mask is a very important prevention measure to limit } \\
\text { the spread of COVID-19. }\end{array}$ \\
\hline $\mathrm{H} 2$ & Hand wash & & 0.24542 & 0.02880 & 11 & $\begin{array}{l}\text { Proper handwashing prevents infections from one person to } \\
\text { others and keeps you healthy. }\end{array}$ \\
\hline $\mathrm{H} 3$ & $\begin{array}{l}\text { Workplace } \\
\text { sanitization }\end{array}$ & & 0.12046 & 0.01414 & 19 & Cleaning and disinfecting the workplace helps to remove germs. \\
\hline $\mathrm{H} 4$ & $\begin{array}{l}\text { Cover cough and } \\
\text { sneezes }\end{array}$ & & 0.11179 & 0.01312 & 21 & $\begin{array}{l}\text { Covering cough and sneeze can help to prevent respiratory } \\
\text { diseases like COVID-19. }\end{array}$ \\
\hline SPI & $\begin{array}{l}\text { Sharing } \\
\text { personal items }\end{array}$ & 0.12494 & & & & $\begin{array}{l}\text { People should avoid sharing their things with others. It is very } \\
\text { difficult to identify how a person is infected. }\end{array}$ \\
\hline SPII & Phone & & 0.12098 & 0.01512 & 18 & $\begin{array}{l}\text { The surface of your phone can be a source of infection. So it is } \\
\text { important to stop sharing your phone prevent coronavirus. }\end{array}$ \\
\hline $\mathrm{SPI} 2$ & Combs & & 0.09851 & 0.01231 & 23 & $\begin{array}{l}\text { People should not share their combs with others to prevent } \\
\text { infection. }\end{array}$ \\
\hline SPI3 & Crockery & & 0.24302 & 0.03036 & 10 & Do not share the crockery items or eating utensils. \\
\hline SPI4 & Sanitary items & & 0.42934 & 0.05364 & 5 & $\begin{array}{l}\text { Sanitary items should not be shared because it could be a source } \\
\text { of COVID. }\end{array}$ \\
\hline SPI5 & Stationary & & 0.10815 & 0.01351 & 20 & Limit sharing your stationery items reduce the spread of germs. \\
\hline UTT & $\begin{array}{l}\text { Unnecessary } \\
\text { touching } \\
\text { things }\end{array}$ & 0.17976 & & & & Be mindful to avoid touching unnecessary things. \\
\hline UTTI & Public objects & & 0.26752 & 0.04809 & 6 & $\begin{array}{l}\text { People must be careful while touching public objects such as ATM } \\
\text { and currency notes. }\end{array}$ \\
\hline UTT2 & Own body parts & & 0.53770 & 0.09666 & 3 & $\begin{array}{l}\text { It is extremely important to avoid touching your body parts, such } \\
\text { as the mouth, eyes, and nose. Often hands touch surfaces, may } \\
\text { pick up the virus, and infect your body. }\end{array}$ \\
\hline
\end{tabular}

(Continued) 
Table 3 (Continued).

\begin{tabular}{|c|c|c|c|c|c|c|}
\hline $\begin{array}{l}\text { PM } \\
\text { Codes }\end{array}$ & Criteria & $\begin{array}{l}\text { Weight } \\
\text { of Main } \\
\text { Criteria }\end{array}$ & $\begin{array}{l}\text { Weight } \\
\text { of Sub- } \\
\text { Criteria }\end{array}$ & $\begin{array}{l}\text { Global } \\
\text { Weights }\end{array}$ & Rank & Brief Description \\
\hline UTT3 & $\begin{array}{l}\text { Doorknob/stair } \\
\text { bannisters }\end{array}$ & & 0.19478 & 0.03501 & 8 & $\begin{array}{l}\text { Touching doorknob, lift button, and stair banisters must be } \\
\text { avoided. }\end{array}$ \\
\hline HD & Healthy Diet & 0.05052 & & & & $\begin{array}{l}\text { It is very important to eat a healthy diet during the COVID-19 } \\
\text { pandemic. A healthy diet enables the body to fight, prevent, and } \\
\text { recover from infections. }\end{array}$ \\
\hline HDI & $\begin{array}{l}\text { Mix whole grain } \\
\text { foods }\end{array}$ & & 0.30376 & 0.01535 & 17 & $\begin{array}{l}\text { Eat mix wholegrain foods such as maize, wheat, beans, and fresh } \\
\text { fruits. These foods are rich in fiber and reduce the risk of } \\
\text { infections. }\end{array}$ \\
\hline HD2 & $\begin{array}{l}\text { Avoid } \\
\text { processed, } \\
\text { baked, and fried } \\
\text { foods }\end{array}$ & & & & & $\begin{array}{l}\text { People must avoid processed foods because it includes artificial } \\
\text { ingredients, trans fat, and refined carbohydrates. It may increase } \\
\text { the risk of infections }\end{array}$ \\
\hline HD3 & $\begin{array}{l}\text { Drink enough } \\
\text { water }\end{array}$ & & 0.52421 & 0.02648 & 13 & $\begin{array}{l}\text { Drinking enough water keeps your mouth moist that can prevent } \\
\text { coronavirus. }\end{array}$ \\
\hline $\mathrm{I} / \mathrm{F}$ & $\begin{array}{l}\text { Immunityl } \\
\text { Fitness }\end{array}$ & 0.06663 & & & & $\begin{array}{l}\text { The immune system is a network of units that work together to } \\
\text { combat invaders, including bacteria, and viruses. Boosting } \\
\text { immunity helps to prevent COVID-19. }\end{array}$ \\
\hline $\mathrm{I} / \mathrm{FI}$ & $\begin{array}{l}\text { Exercise } \\
\text { regularly }\end{array}$ & & 0.29364 & 0.01957 & 16 & $\begin{array}{l}\text { The experts recommend do exercising moderately boost } \\
\text { immunity to fight against COVID-19. }\end{array}$ \\
\hline I/F2 & $\begin{array}{l}\text { Get adequate } \\
\text { sleep }\end{array}$ & & 0.32599 & 0.02172 & 15 & $\begin{array}{l}\text { Getting enough sleep support the immunity system. It minimizes } \\
\text { risk infections and can improve health for fighting the viruses. }\end{array}$ \\
\hline I/F3 & Minimize stress & & 0.19573 & 0.01304 & 22 & $\begin{array}{l}\text { The coronavirus may cause stress for people because it disrupts } \\
\text { daily routines. Reducing stress minimizes the risk of infections. }\end{array}$ \\
\hline $\mathrm{I} / \mathrm{F} 4$ & $\begin{array}{l}\text { Maintain } \\
\text { a healthy weight }\end{array}$ & & 0.18464 & 0.01230 & 24 & $\begin{array}{l}\text { Eating a balanced diet to maintain a healthy weight during COVID. } \\
\text { Overweight may put you at risk for diseases. }\end{array}$ \\
\hline $\mathrm{MH}$ & $\begin{array}{l}\text { Monitor your } \\
\text { health }\end{array}$ & 0.09533 & & & & $\begin{array}{l}\text { Frequently monitoring your health is an important aspect to } \\
\text { prevent COVID. }\end{array}$ \\
\hline MHI & $\begin{array}{l}\text { Shortness of } \\
\text { breath }\end{array}$ & & 0.11943 & 0.01141 & 25 & $\begin{array}{l}\text { Shortness of breath is also called dyspnea. The coronavirus attacks } \\
\text { the lungs and respiratory system. So it is important to perform an } \\
\text { exercise to avoid such infections. }\end{array}$ \\
\hline $\mathrm{MH} 2$ & Fever & & 0.28028 & 0.02678 & 12 & $\begin{array}{l}\text { Fever is also known as elevated temperature. If body temperature } \\
\text { is higher than normal. Frequently check the body temperature } \\
\text { may help to prevent the virus. }\end{array}$ \\
\hline $\mathrm{MH} 3$ & Sore throat & & 0.36246 & 0.03464 & 9 & $\begin{array}{l}\text { According to CDC sore throat is an early symptom of COVID-19, } \\
\text { because the virus inhaled through the nose and throat. So, people } \\
\text { must cover your nose and mouth to prevent the ailment. }\end{array}$ \\
\hline $\mathrm{MH} 4$ & $\begin{array}{l}\text { Congestion/ } \\
\text { runny nose }\end{array}$ & & 0.23764 & 0.02270 & 14 & $\begin{array}{l}\text { Congestion/runny nose is also considered as hallmarks of the } \\
\text { novel COVID-19. }\end{array}$ \\
\hline
\end{tabular}


comparison matrix of the main criteria as well as subcriteria. Pairwise comparison matrices have been developed to determine the weights of every criterion. AHP method was utilized to calculate the weights of pandemic COVID-19 preventive measures. The results of this research are presented in Table 2. The major preventive measures: social distance hold the highest weight (0.36525), unnecessary touching things (0.17976), sharing personal items $(0.12494)$, hygiene $(0.11736)$, monitor your health (0.09553), immunity/fitness (0.06663), and healthy diet (0.05052). The priority weights of main criteria along with sub-criteria have been presented in Table 3. The global weights/cumulative weights of each sub-criteria have been computed, to prioritize them. The consistency ratio has also been checked and the results are tolerable. Further, the importance of every criterion has been discussed.

\section{Discussions}

The new virus known as COVID-19 began in China. This disease spread from infected person to person. It also transmits from people's nose droplets or cough. A multi-criteria decision making analysis is used to analyze and prioritize the COVID-19 precautionary measures.

Social distancing is ranked top. It means people should keep 1 meter ( 3 feet) distance between them. It is also important people should avoid unnecessary travel, handshaking, hugging, and crowded areas.

Hygiene plays a vital role to limit the spread of the virus. Wearing a face mask is mandatory. Regular hand washing/sanitizing and cover the mouth while sneezing or cough. Proper cleaning and disinfection of the workplace are essential to prevent this virus. Sharing personal items such as phone, comb, crockery, stationery, and sanitary items should be discouraged. People may catch the virus by touching unnecessary objects such as public objects, their body parts, doorknob/bannister. So, avoid unnecessary touching these objects can defeat COIVD-19.

A balanced diet helps the body to combat, avoid, and recover from infections. Drinking enough water and getting adequate sleep also improve health. Doing regular exercise enhances immunity systems to fight against this virus. People should monitor their health properly, anyone who is feeling sick/shortness of breath, sore throat, and runny nose. They must consult the physician to prevent this novel coronavirus.

\section{Implications}

Overall, the significant strength of this research was to analyze and prioritize the various SARS-CoV-2 precautionary measure to reduce transmission of this infection. For this purpose, a multi-criteria decision-making method was applied. Our findings demonstrated that social distancing, unnecessary travel, $3 \mathrm{Cs}$, and unnecessary touching own body part should be avoided. Wearing a face mask, proper hand washing/sanitizing, and maintain a healthy diet is important to prevent the coronavirus.

This scientific research prioritizes the infection prevention and controls precautionary of SARS-CoV-2 informed by the World Health Organization (WHO), CDC, and UNICEF, etc. However, the researchers made a possible effort to consider theoretical and methodological insights in this study.

\section{Conclusion}

The COVID-19 epidemic has affected 215 countries around the world. It is approximately said to have affected more than 11 million people around the globe. The WHO, $\mathrm{CDC}$, and other governing bodies provided guidelines to stop the spread of coronavirus. These guidelines and precautionary measures have been selected in this research. A multi-criteria decision-making method was utilized to prioritize the various preventive measures to determine the impact, importance, and role of spreading the coronavirus disease.

Unnecessary travel and 3Cs (spaces that are closed, crowded, and involve close contacts) have been found, to have the greatest influence and the most significant factor in the spread of coronavirus. Unnecessary touching own body parts, shaking hands, and hugging peoples are the subsequent important issues in the same. All main preventive measures (criteria) along with sub-criteria have been ranked according to their importance. Many other preventive measures as well as other decision-making methods may also be considered in future research to assess the spread of coronavirus.

\section{Ethical Approval}

Not required. The COIVD-19 precautionary measure/prevention guidelines are considered for human care and freely available at WHO, CDC, UNICEF websites.

\section{Funding}

There is no funding to report. 


\section{Disclosure}

The authors declare no conflicts of interest for this work.

\section{References}

1. Gao X, Yu J. Public governance mechanism in the prevention and control of the COVID-19: information, decision-making and execution. J Chin Governance. 2020;5(2):178-197. doi:10.1080/ 23812346.2020 .1744922

2. How COVID-19 spreads. U.S. Centers for Disease Control and Prevention (CDC); September 18, 2020.Retrieved September 20, 2020. Available from: https://www.cdc.gov/coronavirus/2019-ncov/pre vent-getting-sick/how-covid-spreads.html.

3. Coronavirus disease (COVID-19): How is it transmitted? World Health Organization (WHO); 2020.Retrieved December 6, 2020. Available from: https://www.who.int/news-room/q-a-detail/corona virus-disease-covid-19-how-is-it-transmitted.

4. Chatterjee SS, Vora M, Malathesh BC, Bhattacharyaa R. Worried well and Covid-19: re-emergence of an old quandary. Asian J Psychiatr. 2020;78:100738.

5. Sun P, Lu X, Xu C, Sun W, Pan B. Understanding of COVID-19 based on current evidence. J Med Virol. 2020;92(6):548-551. doi:10.1002/ jmv. 25722

6. Maragakis LL. First and second waves of coronavirus. John Hopkin University; 2020. Available from: https://www.hopkinsmedicine.org/ health/conditions-and-diseases/coronavirus/first-and-second-waves-ofcoronavirus. Accessed February 17, 2021.

7. Regulatory Affairs Professionals Society. COVID-19 vaccine tracker; 2020. Available from: https://www.raps.org/news-and-articles/newsarticles/2020/3/covid-19-vaccine-tracker. Accessed February 17, 2021.

8. Sohrabi C, Alsafi Z, Neill N, et al. World health organization declares global emergency: a review of 2019 the novel coronavirus. Int J Surg. 2020;76:71-760. doi:10.1016/j.ijsu.2020.02.034
9. Singh R, Avikal S. COVID-19: a decision-making approach for prioritization of preventive activities. Int J Healthc Manag. 2020;13 (3):257-262. doi:10.1080/20479700.2020.1782661

10. Coronavirus Disease. (COVID-19) situation report - 43 (2020); 2019b. World Health Organization; 2020. Available from: https:// www.who.int/docs/default-source/coronaviruse/situation-reports/ 20200303-sitrep-43-covid-19.pdf?sfvrsn=76e425ed_2.

11. Wu D, Lu J, Liu Y, Zhang Z, Luo L. Positive effects of COVID-19 control measures on influenza prevention. Int $J$ Infect Dis. 2020;95:345-346. doi:10.1016/j.ijid.2020.04.009

12. Ferrari Neto G, Leal GCL, Galdamez EVC, Souza RCTD. Prioritization of occupational health and safety indicators using the Fuzzy-AHP method. Production. 2020;30:1-13.

13. Barbosa C, Azevedo R, Rodrigues MA. Occupational safety and health performance indicators in SMEs: a literature review. Work. 2019;64(2):217-227. doi:10.3233/WOR-192988

14. Emshoff JR, Saaty TL. Applications of the analytic hierarchy process to long range planning processes. Eur J Oper Res. 1982;10 (2):131-143. doi:10.1016/0377-2217(82)90153-9

15. Saaty TL, Vargas LG. Prediction, Projection, and Forecasting: Applications of the Analytic Hierarchy Process in Economics, Finance, Politics, Games, and Sports. Kluwer Academic Pub; 1991.

16. Ikram M, Zhang Q, Sroufe R. Developing integrated management systems using an AHP-Fuzzy VIKOR approach. Bus Strat Environ. 2020;29(1):2265-2283. doi:10.1002/bse.2501

17. Yousefzadeh S, Yaghmaeian K, Mahvi AH, Nasseri S, Alavi N, Nabizadeh R. Comparative analysis of hydrometallurgical methods for the recovery of $\mathrm{Cu}$ from circuit boards: optimization using response surface and selection of the best technique by two-step fuzzy AHP-TOPSIS method. J Clean Prod. 2020;249:119401. doi:10.1016/j.jclepro.2019.119401

18. Sarraf R, McGuire MP. Integration and comparison of multi-criteria decision making methods in safe route planner. Expert Syst Appl. 2020;154:113399. doi:10.1016/j.eswa.2020.113399
Journal of Healthcare Leadership

\section{Publish your work in this journal}

The Journal of Healthcare Leadership is an international, peer-reviewed, open access journal focusing on leadership for the health profession. The journal is committed to the rapid publication of research focusing on but not limited to: Healthcare policy and law;Theoretical and practical aspects healthcare delivery; Interactions between healthcare and society and evidence-based practices; Interdisciplinary decision-making;
Philosophical and ethical issues; Hazard management; Research and opinion for health leadership; Leadership assessment. The manuscript management system is completely online and includes a very quick and fair peer-review system. Visit http://www.dovepress.com/ testimonials.php to read real quotes from published authors. 